\title{
Differential alterations in peripheral lymphocyte subsets in COVID-19 patients: upregulation of double-positive and double-negative T cells
}

\author{
Asmaa M. Zahran, ${ }^{1}$ Zeinab Albadry M. Zahran, ${ }^{2}$ Yasmeen H. Mady, ${ }^{1}$ Essam Eldeen M.O. Mahran, ${ }^{3}$ Alaa Rashad, ${ }^{4}$ \\ Ahmed Makboul, ${ }^{1}$ Khalid A. Nasif, ${ }^{5,6}$ Aida A. Abdelmaksoud, ${ }^{7}$ Omnia El-Badawy ${ }^{8}$ \\ ${ }^{1}$ Department of Clinical Pathology, South Egypt Cancer Institute, Assiut University, Assiut, Egypt \\ ${ }^{2}$ Department of Clinical Pathology, Faculty of Medicine, Assiut University, Assiut, Egypt \\ ${ }^{3}$ Department of Tropical Medicine and Gastroenterology, Faculty of Medicine, Assiut University, Assiut, Egypt \\ ${ }^{4}$ Department of Chest Diseases and Tuberculosis, Qena Faculty of Medicine, South Vally-University, Qena, Egypt \\ ${ }^{5}$ Department of Biochemistry, Faculty of Medicine, Minia University, Minia, Egypt \\ ${ }^{6}$ College of Medicine, King Khalid University, Abha, Saudi Arabia \\ ${ }^{7}$ Department of E.N.T., Qena Faculty of Medicine, South Valley University, Qena, Egypt \\ ${ }^{8}$ Department of Medical Microbiology and Immunology, Faculty of Medicine, Assiut University, Assiut, Egypt
}

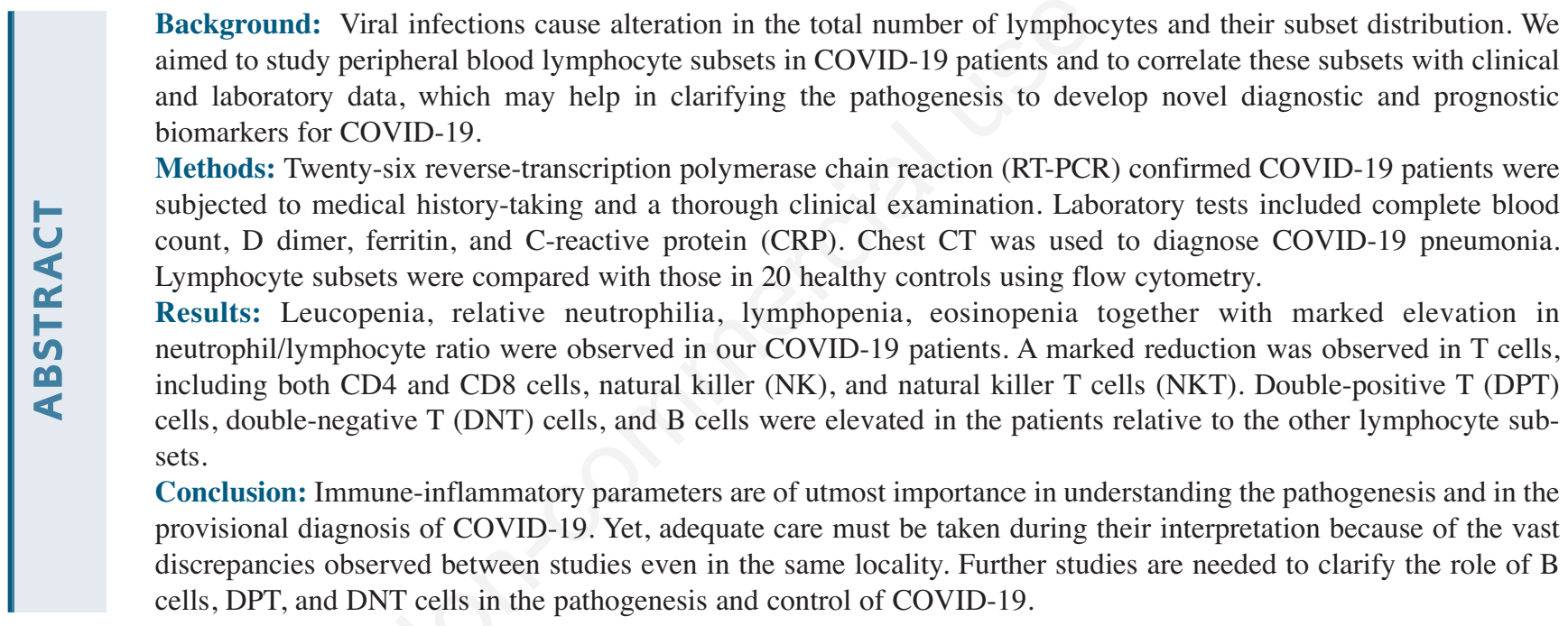

Key words: COVID-19; SARS-CoV-2; lymphocyte subsets; double-positive T cells; double-negative T cells.

Correspondence: Alaa Rashad, Department of Chest Diseases and Tuberculosis, Qena Faculty of Medicine, South ValleyUniversity, Qena, Egypt. Tel.+20.1060531155. E-mail: alaasma27@med.svu.edu.eg

Contributions: AMZ, OEB, contributed to the study conception and design; ZAMZ, YHM, first of manuscript draft. All authors performed material preparation, data collection and analysis, commented previous versions of the manuscript, read and approved the final version of the manuscript and agreed to be accountable for all aspects of the work.

Conflict of interest: The authors declare that they have no competing interests, and all authors confirm accuracy.

Funding: The researchers did not receive any grants from funding agencies.

Availability of data and materials: All data generated or analyzed during this study are included in this published article.

Ethics approval and consent to participate: The study was reviewed and accepted by the Institutional Ethics Committee, IRB no. 17300436. Informed consent was obtained from all participants before joining the study. 


\section{Introduction}

Coronaviruses (CoVs) are well-known causes of severe infections; respiratory, enteric, and systemic, in humans and numerous animal hosts. In December 2019, an increasing number of cases of pneumonia of unknown etiology was reported in Wuhan, Hubei Province, China. Several studies suggested that the disease was caused by a novel coronavirus that has been transferred from animals [1]. The virus was termed SARS-CoV-2, and the disease was designated coronavirus disease 2019 (COVID-19) by the World Health Organization (WHO) [2]. Patients with COVID-19 have several symptoms such as fever, dry cough, bone pain, and fatigue in the early stage. Later, patients may develop acute respiratory distress syndrome (ARDS) that eventually evolves into shock, respiratory failure, serious multiorgan failure, or even death [3]. In Egypt, according to the Egyptian Ministry of Health's daily reports, SARS-CoV-2 has infected 185,587 patients and has caused 10,871 deaths (as of March $4^{\text {th }}, 2021$ ).

Infection by SARS-CoV-2 can result in excessive production of cytokines and chemokines (namely a cytokine storm), resulting in immune dysregulation and patient mortality [4]. Viral infections are known to cause alteration in the total number of lymphocytes, and their subsets vary with the different virus types. Lymphocyte subsets play a crucial role in the preservation of immune system function. This indicates the potential association between lymphocyte subset alterations and the mechanism of viral pathogenicity [5].

Recent studies indicated a clear decrease in peripheral lymphocytes in COVID-19 patients [6]. Also, there is a growing list of publications reporting that the assessment of lymphocyte subset counts can provide prognostic information for COVID-19 disease severity and convalescence when these findings are correlated with other clinical data $[7,8]$.

Little is known about theses lymphocyte subset counts in Egyptian COVID-19 patients. Thus, we aimed to study peripheral blood lymphocyte subsets in COVID-19 patients and to correlate these subsets with clinical and laboratory data, which may help in clarifying the pathogenesis to develop novel diagnostic and prognostic biomarkers for COVID-19.

\section{Materials and Methods}

Our pilot study included a cohort of 26 reverse-transcription polymerase chain reaction (RT-PCR) confirmed COVID-19 patients, and 20 age and sex-matched healthy volunteers. All data and laboratory investigation were obtained at day one hospital admission and before the start of any medication for treatment of COVID-19 symptoms. Patients with known hematological disorders or other chronic diseases were excluded from our study. Patients were subjected to medical history-taking and a thorough clinical examination including oxygen saturation and measurement of $\mathrm{PaO}_{2} / \mathrm{FiO}_{2}$ ratio. Baseline laboratory tests included complete blood count and levels of hemoglobin ( $\mathrm{Hb}), \mathrm{D}$ dimer, ferritin, and C-reactive protein (CRP). Neutrophil to lymphocyte ratio (NLR) was calculated by dividing the absolute neutrophil count by absolute lymphocyte count.

The diagnosis of COVID-19 pneumonia was established considering the following chest CT patterns: ground-glass opacity (GGO), crazy-paving, and consolidation $[9,10]$. The CT findings were in accordance with the standard glossary for thoracic imaging reported by the Fleischner Society [11]. A semi-quantitative CT severity scoring was calculated per each of the five lobes, as was described by Pan et al. [12], considering the extent of anatomic involvement, as follows; 0 : no involvement; $1:<5 \%$ involvement;
2: 5-25\% involvement; 3: 26-50\% involvement; 4: 51-75\% involvement; and 5: $>75 \%$ involvement. The resulting global CT score was the sum of each lobar score and ranged from 0 to a maximum value of 25 .

\section{Flow cytometric detection of lymphocyte subsets}

Whole blood samples collected in EDTA tubes were analysed by flow cytometry. For the detection of lymphocytes, $50 \mu \mathrm{l}$ of a whole blood sample was stained with $10 \mu \mathrm{l}$ of fluoroisothiocyanate (FITC)-conjugated anti-CD3, phycoerythrin (PE)-conjugated antiCD16/56, pyridinium-chlorophyll-protein (Per-CP)-conjugated anti-CD19 in one tube. For lymphocyte subset analysis, a second tube was stained with FITC conjugated anti-CD4, PE-conjugated anti-CD8, and Per-Cp conjugated anti-CD3. All previously mentioned monoclonal antibodies were purchased from Becton Dickinson (BD) Biosciences (San Jose, CA, USA). After incubation for 15 minutes, red blood cell lysis and washing were done, and the cells were resuspended in phosphate-buffered saline (PBS). 20,000 cells were acquired by FACS Calibur flow cytometer, and analysis was carried out using BD Cell Quest Pro software. Anti-human IgG was used as an isotype-matched negative control for each sample. Forward and side scatter dot plot was used to define the lymphocyte population. Then, the percentages of CD19 ${ }^{+}$ (B-lymphocytes), cells, $\mathrm{CD}^{+} \quad$ (T-lymphocytes), $\mathrm{CD}^{+} \mathrm{CD} 16^{+} \mathrm{CD} 56^{+}(\mathrm{NKT})$ and $\mathrm{CD} 3-\mathrm{CD} 16^{+} \mathrm{CD} 56^{+}$natural killer (NK) cells, were calculated. Next, further sub-classification of the T-lymphocyte population $\left(\mathrm{CD}^{+}\right)$into: $\mathrm{CD}^{+}$(T-helper), $\mathrm{CD}^{+}(\mathrm{T}-$ cytotoxic), double-positive T-lymphocytes $\left(\mathrm{CD} 4^{+} \mathrm{CD} 8^{+}\right)$and double-negative T-lymphocytes (CD4-CD8-) was done (Figure 1).

\section{Statistical analysis}

Statistical analysis was done using the IBM Statistical Package for the Social Sciences (IBM SPSS statistics, version 20). Categorical data were displayed as numbers and percentages, while continuous data were presented as the mean and standard error. Mann-Whitney U test was used to compare groups, and Spearman's rank correlation was employed to evaluate the strength of association between different variables.

\section{Results}

Demographic characteristics, clinical presentation, and some laboratory features of COVID-19 patients

The mean age of the patients' group was $32.3 \pm 15$ years. Out of these 26 patients, $20(77 \%)$ were males and $6(23 \%)$ were females. Table 1 presents some clinical and laboratory features of COVID19 patients. Twenty-three patients $(88.5 \%)$ had fever, $18(69.2 \%)$ had cough, $13(50 \%)$ had dyspnea, $6(23 \%)$ had anosmia and 4 (15.4\%) had diarrhea. Regarding chest CT findings, 13 (50\%) were mild cases ( 7 patients with the score "1" and 6 with score "2"), seven $(26.9 \%)$ were moderate cases (3 patients with the score " 3 " and 4 with the score " 4 ") and six (23\%) were severe cases (score 5), regarding $\mathrm{PaO}_{2} / \mathrm{FiO}_{2}, 10$ patients $(38.5 \%$ ) had values $>300,9$ $(34.6 \%)$ had values $\leq 300 \geq 200$ and $7(26.9 \%)<200$.

Also, in the patients' group, the mean value of $\mathrm{Hb}$ concentration was $12 \pm 2 \mathrm{~g} / \mathrm{dL}, \mathrm{C}$-reactive protein (CRP) was $37.4 \pm 10 \mathrm{mg} / \mathrm{dL}$, ferritin was $552.5 \pm 88 \mathrm{ng} / \mathrm{mL}$, D-dimer was $389.7 \pm 54 \mu \mathrm{g} / \mathrm{L}$. Levels of ferritin increased markedly with disease severity (mild: 276.5 \pm 45 ; moderate: $563.7 \pm 133$; and severe: $1137.5 \pm 178$ ). The same was observed in the levels of D dimer (mild: $289.2 \pm 50$; moderate: $417.2 \pm 112$; and severe:575.4 \pm 142 ) and CRP (mild: $22.6 \pm 7$; moderate: $52.9 \pm 29$; and severe: $51.5 \pm 27$ ), yet with no many differences between moderate and severe cases. 


\section{Immune cells in COVID-19 patients and the control group}

As presented in Table 2, the mean leukocyte count for the patient group $\left(5.7 \pm 0.5 \times 10^{9} / \mathrm{L}\right)$ was lower than that for the control group $\left(7.4 \pm 0.4 \times 10^{9} / \mathrm{L}\right)$, with a statistically significant difference between the two groups $(p=0.008)$. Initially, total leucocyte count (TLC) was low in the mild cases then increased, inconsistently, in some moderate and severe cases. Both relative and absolute eosinophil counts were obviously lower in COVID-19 patients than controls $(2.4 \pm 0.4 v s 4 \pm 0.4, \mathrm{p}=0.003$ and $0.1 \pm 0.02$ vs $0.3 \pm 0.03$, respectively, $\mathrm{p}<0.0001)$ and to some extent lower in severe cases.

The relative neutrophil count was $68 \pm 2 \%$ for the patient group and $46.4 \pm 2 \%$ for the control group with a highly significant difference between both groups ( $p<0.0001)$, the mean absolute neutrophil count was not different between both groups $(p=0.1)$. Eleven patients $(52 \%)$ had lymphopenia $<1 \times 10^{9} / \mathrm{L}$ and both the mean relative and absolute lymphocyte counts were significantly reduced in patients than in the controls $\left(21 \pm 2 \times 10^{9} / \mathrm{L} v s 42.4 \pm 2 \times 10^{9} / \mathrm{L}\right.$, $\mathrm{p}<0.0001$ and $1 \pm 0.1 \times 10^{9} / \mathrm{L}$ vs $3 \pm 0.3 \times 10^{9} / \mathrm{L}$, respectively, $\mathrm{p}<0.0001)$. The NLR was markedly elevated in the COVID patients $(2.3 \pm 0.2)$ than in the healthy controls $(0.9 \pm 0.08), \mathrm{p}<0.0001$, but did not show significant changes with disease severity.

A significant drop was observed in both the mean relative and absolute counts of T-cells in the patient group compared with the control group $(61.4 \pm 2 \%$ vs $69.9 \pm 3 \%, \mathrm{p}=0.003$ and $0.7 \pm 0.01 \mathrm{x}$ $10^{9} / \mathrm{L}$ vs $2.3 \pm 0.2 \times 10^{9} / \mathrm{L}, \mathrm{p}<0.0001$, respectively). Similarly, lower relative and absolute counts of CD4 ${ }^{+}$T-cells $(49 \pm 2 \%$ vs $55.9 \pm 2 \%$, $\mathrm{p}=0.005$ and $0.3 \pm 0.03 \times 10^{9} / \mathrm{L}$ vs $1.3 \pm 0.1 \times 10 \% / \mathrm{L}, \mathrm{p}<0.0001$, respectively) and $\mathrm{CD}^{+}$T-cells $(29 \pm 1 \%$ vs $34.3 \pm 2 \%, \mathrm{p}=0.01$ and
Table 1. Clinical presentation and some laboratory features of COVID-19 patients.

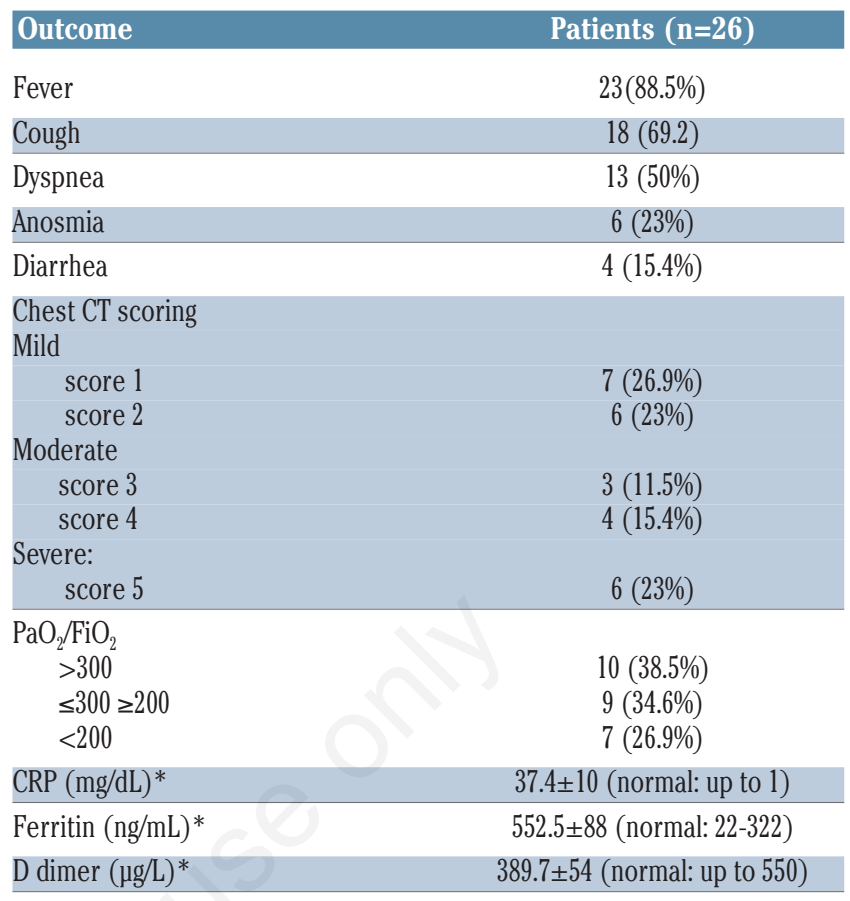

Results expressed as number (percent) or *mean \pm SE (normal range). GIT, gastrointestinal tract; CT, computed tomography; $\mathrm{PaO}_{2}$, arterial $\mathrm{O} 2$ tension; $\mathrm{FiO}_{2}$, fraction inspired oxygen; CRP, Creactive protein.
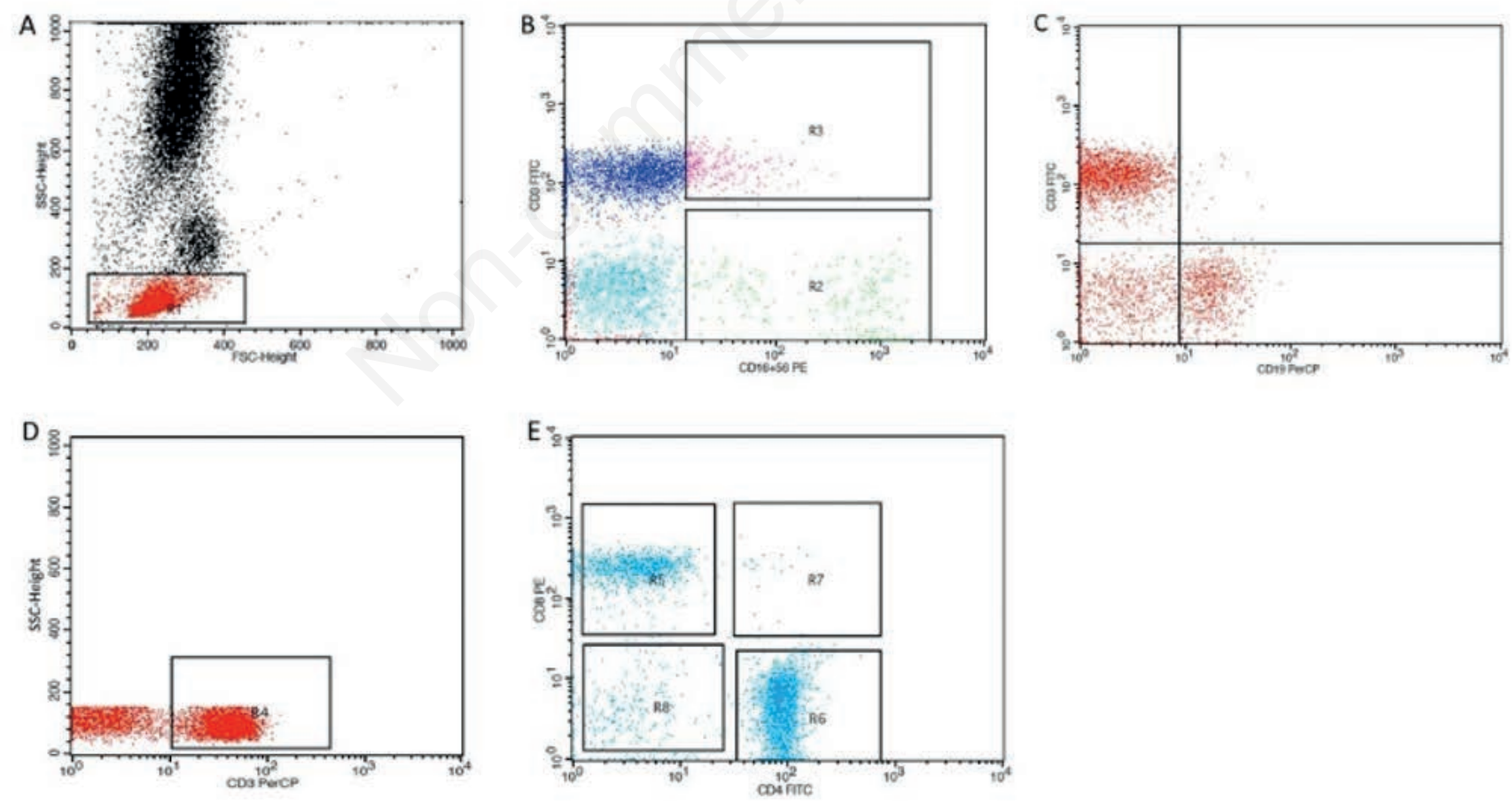

Figure 1. Flow cytometric analysis of lymphocyte subsets in COVID-19 patients. A) Forward and side scatter dot plot was used to define the lymphocyte population (R1). B) The expression of CD16/56 and CD3 was assessed on the lymphocyte population to detect NK and NKT cells. C) The expression of CD3 and CD19 was calculated on lymphocytes to detect B and T lymphocytes. D) CD3 ${ }^{+}$T-lymphocytes were then gated for further analysis of CD4 and CD8. E) The expression of CD4 and CD8 on the CD3 ${ }^{+}$T-lymphocytes was evaluated to detect $\mathrm{CD4}^{+}$( $\mathrm{T}$ helper), $\mathrm{CD8}^{+}$( $\mathrm{T}$ cytotoxic), double positive T-lymphocytes $\left(\mathrm{CD4}^{+} \mathrm{CD8}^{+}\right)$and double negative $\mathrm{T}-\mathrm{lym}$ phocytes $\left(\mathrm{CD}^{-} \mathbf{C D 8}^{-}\right)$. 
$0.2 \pm 0.02 \times 10^{9} / \mathrm{L}$ vs $0.8 \pm 0.09 \times 10^{9} / \mathrm{L}, \mathrm{p}<0.0001$, respectively) were found in patients than in controls. No significant differences were detected in the CD4/CD8 ratio between patients and controls and no obvious relations were detected between $\mathrm{CD}^{+}$and $\mathrm{CD}^{+} \mathrm{T}$-cell counts and the CT severity scores.

On the contrary, the double-positive $\left(\mathrm{CD} 4^{+} \mathrm{CD} 8^{+}\right) \mathrm{T}$ cells relative and absolute counts raised remarkably in patients than in controls $\left(6.2 \pm 0.3 \%\right.$ vs $1.2 \pm 0.04 \%, \mathrm{p}=0.001$ and $0.05 \pm 0.004 \times 10^{9} / \mathrm{L} v s$ $0.03 \pm 0.003 \times 10^{9} / \mathrm{L}, \mathrm{p}<0.0001$, respectively). While the mean absolute count of the double-negative (CD4-CD8-) T-cells significantly decreased in the patient group, the relative count was higher in the patients than in the control group $\left(0.1 \pm 0.009 \times 10^{9} / \mathrm{L}\right.$ vs $0.2 \pm 0.03 \mathrm{x}$ $10^{9} / \mathrm{L}, \mathrm{p}=0.001$ and $14.7 \pm 0.8 \%$ vs $8.6 \pm 0.6 \%, \mathrm{p}<0.0001$, respectively). Likewise, the mean absolute count of B-lymphocytes decreased in the patients and the relative count elevated in the patients compared with the controls $\left(0.2 \pm 0.02 \times 10^{9} / \mathrm{L} v_{s} 0.4 \pm 0.03 \times 10^{9} / \mathrm{L}\right.$, $\mathrm{p}<0.0001$ and $19.2 \pm 0.9 \%$ vs $11.6 \pm 0.4 \%, \mathrm{p}<0.0001$, respectively). Furthermore, the relative and absolute counts of natural killer (NK) cells were lower in patients than in the healthy controls $(8.9 \pm 0.3 \%$ vs $10.4 \pm 0.6 \%, \mathrm{p}=0.02$ and $0.09 \pm 0.007 \times 10^{9} / \mathrm{L}$ vs $0.3 \pm 0.03 \times 10^{9} / \mathrm{L}$, $\mathrm{p}<0.0001$, respectively). The relative and absolute counts of NKT cells also were reduced in the patients than in the controls $(6.2 \pm 0.4 \%$ vs $8.5 \pm 0.4 \%, \mathrm{p}<0.0001$ and $0.06 \pm 0.006 \times 10 \% / \mathrm{L}$ vs $0.3 \pm 0.02 \times 10^{9} / \mathrm{L}, \mathrm{p}<0.0001$, respectively).

\section{Correlations between the different lymphocyte subsets and laboratory and clinical findings in patients with COVID-19}

Analysis of the relations of the different lymphocyte subsets with the laboratory and clinical findings revealed several significant correlations. The NLR showed positive correlation with CRP $(\mathrm{r}=0.6, \mathrm{p}=0.005)$ and duration of anosmia $(\mathrm{r}=0.4,0.049)$ and negatively correlate with $\mathrm{PaO}_{2} / \mathrm{FiO}_{2}(\mathrm{r}=-0.7, \mathrm{p}=0.01)$. Also, the eosinophil count had a negative correlation with the level of ferritin $(\mathrm{r}=-0.6, \mathrm{p}=0.001)$. The duration of fever was inversely related to the relative count of $\mathrm{CD}^{+} \mathrm{T}$ lymphocytes $(\mathrm{r}=-0.5, \mathrm{p}=0.01)$ and positively related to the relative counts of the double-positive ( $\mathrm{r}=$ $0.6,0.002)$ and double-negative $\mathrm{T}$ lymphocytes $(\mathrm{r}=0.5,0.003)$.

Table 2. Alterations in immune cells in COVID-19 patients.

\begin{tabular}{|c|c|c|c|}
\hline Immune cells & Patients $(n=26)$ & Controls $(\mathrm{n}=20)$ & $\mathbf{p}^{*}$ \\
\hline $\operatorname{TLC}\left(\times 10^{9} / \mathrm{L}\right)$ & $5.7 \pm 0.5$ & $7.4 \pm 0.4$ & 0.008 \\
\hline $\begin{array}{l}\text { Eosinophils } \\
\text { Relative to lymphocyte count (\%) } \\
\text { Absolute count (x 10\%) }\end{array}$ & $\begin{array}{c}2.4 \pm 0.4 \\
0.1 \pm 0.02\end{array}$ & $\begin{array}{c}4 \pm 0.4 \\
0.3 \pm 0.03\end{array}$ & $\begin{array}{l}<0.0001 \\
<0.0001\end{array}$ \\
\hline $\begin{array}{l}\text { Neutrophils } \\
\text { Relative to lymphocyte count (\%) } \\
\text { Absolute count }\left(\times 10^{9} / \mathrm{L}\right)\end{array}$ & $\begin{array}{l}68 \pm 2 \\
4 \pm 0.4\end{array}$ & $\begin{array}{l}46.4 \pm 2 \\
3.4 \pm 0.2\end{array}$ & $\begin{array}{c}<0.0001 \\
0.1\end{array}$ \\
\hline $\begin{array}{l}\text { Lymphocyte } \\
\text { Relative to lymphocyte count (\%) } \\
\text { Absolute count (x 109) }\end{array}$ & $\begin{array}{l}21 \pm 2 \\
1 \pm 0.1\end{array}$ & $\begin{array}{c}42.4 \pm 2 \\
3 \pm 0.3\end{array}$ & $\begin{array}{l}<0.0001 \\
<0.0001\end{array}$ \\
\hline $\begin{array}{l}\text { Neutrophil/lymphocyte ratio } \\
\left.\text { T-lymphocytes (CD }{ }^{+}\right) \\
\text {Relative to lymphocyte count (\%) }\end{array}$ & $\begin{array}{l}2.3 \pm 0.2 \\
61.4 \pm 2\end{array}$ & $\begin{array}{l}0.9 \pm 0.08 \\
69.9 \pm 3\end{array}$ & $\begin{array}{c}<0.0001 \\
0.003\end{array}$ \\
\hline $\begin{array}{l}\text { Absolute count }\left(\times 10^{9} / \mathrm{L}\right) \\
\text { CD4+ T-lymphocytes } \\
\text { Relative to CD } 3^{+} \text {-lymphocyte count }(\%) \\
\text { Absolute count }\left(\times 10^{9} / \mathrm{L}\right)\end{array}$ & $\begin{array}{c}0.7 \pm 0.01 \\
49 \pm 2 \\
0.3 \pm 0.03\end{array}$ & $\begin{array}{l}2.3 \pm 0.2 \\
55.9 \pm 2 \\
1.3 \pm 0.1\end{array}$ & $\begin{array}{l}<0.0001 \\
0.005 \\
<0.0001\end{array}$ \\
\hline $\begin{array}{l}\text { CD8+ T-lymphocytes } \\
\text { Relative to CD3+T-lymphocyte count (\%) } \\
\text { Absolute count (x 10\% } / \mathrm{L}) \\
\text { CD4/CD8 ratio }\end{array}$ & $\begin{array}{c}29 \pm 1 \\
0.2 \pm 0.02 \\
1.8 \pm 0.2\end{array}$ & $\begin{array}{c}34.3 \pm 2 \\
0.8 \pm 0.09 \\
1.8 \pm 0.1\end{array}$ & $\begin{array}{c}0.01 \\
<0.0001 \\
0.8\end{array}$ \\
\hline $\begin{array}{l}\text { Double positive T-lymphocytes }\left(\mathrm{CD} 4^{+} / \mathrm{CD}^{+}\right) \\
\text {Relative to } \mathrm{CD} 3^{+} \mathrm{T} \text {-lymphocytes count }(\%) \\
\text { Absolute count }\left(\mathrm{x} 10^{9} / \mathrm{L}\right)\end{array}$ & $\begin{array}{c}6.2 \pm 0.3 \\
0.05 \pm 0.004\end{array}$ & $\begin{array}{c}1.2 \pm 0.04 \\
0.03 \pm 0.003\end{array}$ & $\begin{array}{c}0.001 \\
<0.0001 \\
\end{array}$ \\
\hline $\begin{array}{l}\text { Double negative T-lymphocytes (CD4-/CD8-) } \\
\text { Relative to CD3+T-lymphocytes count (\%) } \\
\text { Absolute count (x 10\%) }\end{array}$ & $\begin{array}{c}14.7 \pm 0.8 \\
0.1 \pm 0.009\end{array}$ & $\begin{array}{c}8.6 \pm 0.6 \\
0.2 \pm 0.03\end{array}$ & $\begin{array}{c}<0.0001 \\
0.001\end{array}$ \\
\hline $\begin{array}{l}\text { B-lymphocytes (CD19+) } \\
\text { Relative to lymphocytes count (\%) } \\
\text { Absolute count }\left(\times 10^{9} / \mathrm{L}\right)\end{array}$ & $\begin{array}{l}19.2 \pm 0.9 \\
0.2 \pm 0.02\end{array}$ & $\begin{array}{l}11.6 \pm 0.4 \\
0.4 \pm 0.03\end{array}$ & $\begin{array}{l}<0.0001 \\
<0.0001\end{array}$ \\
\hline $\begin{array}{l}\text { Natural killer }\left(\mathrm{CD} 16^{+} \mathrm{CD} 56^{+}\right) \\
\text {Relative to lymphocytes count (\%) } \\
\text { Absolute count }\left(\mathrm{x} 10^{9} / \mathrm{L}\right)\end{array}$ & $\begin{array}{c}8.9 \pm 0.3 \\
0.09 \pm 0.007\end{array}$ & $\begin{array}{l}10.4 \pm 0.6 \\
0.3 \pm 0.03\end{array}$ & $\begin{aligned} & 0.02 \\
< & 0.0001\end{aligned}$ \\
\hline $\begin{array}{l}\text { NKT cells }\left(\mathrm{CD} 3^{+} \mathrm{CD} 16^{+} \mathrm{CD} 56^{+}\right) \\
\text {Relative to lymphocytes count }(\%) \\
\text { Absolute count }(\mathrm{x} \mathrm{10} / \mathrm{L})\end{array}$ & $\begin{array}{c}6.2 \pm 0.4 \\
0.06 \pm 0.006\end{array}$ & $\begin{array}{c}8.5 \pm 0.4 \\
0.3 \pm 0.02\end{array}$ & $\begin{array}{l}<0.0001 \\
<0.0001\end{array}$ \\
\hline
\end{tabular}

*Mann-Whitney U test (p-value is significant if $<0.05$ ). Results are expressed as mean \pm SE. TLC, total leucocytic count; NKT, natural killer T cells. 


\section{Discussion}

Hematological changes are known to occur in SARS-CoV-2 virus infection and are often useful in the monitoring of the infection course or to indicate the severity of COVID-19 [13]. As wellknown markers of systemic inflammation and infection, CRP and ferritin have been studied as predictors of bacterial infections, including pneumonia [14], and together with D dimer may be used to predict severe and fatal COVID-19 in hospitalized patients $[15,16]$. Our patients had more elevated CRP, ferritin, and D dimer than the normal reference ranges. Also, their levels increased with disease progression, especially, ferritin and D dimer.

In line with Qin et al. [14], most of our patients presented with significant leucopenia, absolute lymphopenia, and relative neutrophilia. Moreover, in previous studies, marked leucopenia, a higher number of neutrophils and a lower number of lymphocytes were more prominent in severe cases $[6,14,17,18]$, signifying an impairment of the immune system during SARS-CoV-2 infection and the serious disruption of internal environment in those severely infected cases. In our patients TLC decreased in mild cases, but tended to increase, inconsistently, in some moderate and severe cases. This increase could be due to co-infections [19], medications as prednisone [20], or inconsistent immune response [19].

Neutrophilia may be initiated by virus-related inflammatory cytokines produced by lymphocytes and endothelial cells [21] to control the virus infection by producing reactive oxygen species (ROS) and other cytotoxic mediators [22] and by the release of neutrophil extracellular traps (NETs), to capture and destroy the virus [23-25]. On the other hand, the decrease or exhaustion of lymphocytes may be because the viral infection causes immune cells to enter an activated state and share in the anti-viral processes, causing profound damage and apoptosis [26].

The NLR is another marker of systemic inflammation and COVID-19 progression that considers both lymphocytes and neutrophils levels [26]. The NLR in another study [27] was increased in patients with severe COVID-19 and had a prognostic value. NLR was markedly elevated in our COVID patients and showed positive correlations with CRP and anosmia but did not show significant changes with disease progression.

Consistent with earlier studies [14,28], both relative and absolute eosinophil counts were reduced in COVID patients and, to some extent, lower in severe cases. Du et al. observed eosinopenia in almost every COVID patient who died [29]. Others deduced that eosinopenia could be used as a reliable diagnostic factor when combined with lymphopenia [30].

Eosinophils have a potent proinflammatory function. and are equipped with molecules that allow them to recognize and respond to respiratory viruses [31]. Eosinopenia takes place in response to factors inducing acute inflammation [32]. The pathophysiology of eosinopenia in COVID-19 is so far not clear but is most probably multifactorial, including inhibition of eosinopoiesis or eosinophil egress from the bone marrow, downregulation of chemokine receptors/adhesion molecules $[32,33]$ or eosinophil apoptosis triggered by type 1-interferons produced during acute infection [34].

Lymphocytes are involved in the humoral and cytotoxic immunity against viral infection. As with immune diseases and other infectious diseases, virus infection can also lead to dysregulation in the levels of lymphocyte subsets [35, 6]. In our study, the absolute count of T-cells $\left(\mathrm{CD}^{+}\right)$, which are the most important immune cells for protection against viral infections [37-39], was significantly decreased in patients. This finding was similar to that reported earlier $[15,40]$.

$\mathrm{T}$ cell maturity occurs in the thymus where $\mathrm{CD} 4^{+} \mathrm{CD} 8^{+}$doublepositive $\mathrm{T}$ cells mature into either $\mathrm{CD}^{+}$or $\mathrm{CD} 8^{+} \mathrm{T}$ cells that leave the thymus to secondary lymphoid organs and are responsible for the adaptive cellular immune responses to clear infections [41-43]. The relative and absolute counts of $\mathrm{CD}^{+}$and $\mathrm{CD}^{+} \mathrm{T}$-cells were significantly decreased in our patients, as was previously reported [36], with no inversion in the CD4/CD8 ratio. While Jiang et al. [44] reported T lymphopenia, and in particular, a decrease of CD8 ${ }^{+}$ T cells in patients with COVID-19, Qin et al. [14] reported that the reduction of $\mathrm{CD}^{+} \mathrm{T}$-cells was common with no significant change in the number of $\mathrm{CD}^{+}$cells.

Despite the negative correlation between the duration of fever and the relative count of $\mathrm{CD}^{+}{ }^{+} \mathrm{T}$ lymphocytes in our patients, no apparent relations were detected between $\mathrm{CD} 4^{+}$and $\mathrm{CD} 8^{+} \mathrm{T}$-cell counts and the CT severity scores. On the contrary, other studies reported an association between disease severity and the decrease in the count of lymphocyte subsets, especially $\mathrm{CD}^{+}, \mathrm{CD}^{+}$, and $\mathrm{CD}^{+} \mathrm{T}$ cells [44-46].

In our study, DPT cell counts increased, pointing to the possible role of these cells in COVID-19 pathogenesis. Data regarding the functions of DPT cells seems to be very controversial, and very case specific. Some studies reported the cytotoxic potential in diseases, including viral infections as human immunodeficiency virus (HIV) and cancer. In contrast, others reported exhibiting a suppressive phenotype in cancer, systemic sclerosis, and inflammatory bowel disease [47].

Besides being a stage in T-cell development, mechanisms behind the peripheral expansion of DPT cells remain uncertain. CD8 expression could be acquired under continuous antigen stimulation of $\mathrm{CD}^{+} \mathrm{T}$ cells [48]. Conversely, $\mathrm{CD} 8^{+} \mathrm{T}$ cells were proposed to co-express CD4 after in vitro activation of human peripheral blood mononuclear cells [49], consequently rendering them susceptible to HIV infection [50]. Also, upregulation of FasL and IFN- $\gamma$, as hence increased antiviral effector functions, were observed after surface ligation of CD4 on $\mathrm{CD} 8^{+} \mathrm{T}$ cells $[51,52]$. Furthermore, DPT cells in patients with urologic cancers were found to be high type- 2 cytokine producers, and favor a $\mathrm{T}$ helper (Th)-2 polarization of CD4 T cells in vitro, at the expense of the protective Th1 functional profile [53].

Likewise, several conflicting data had been published regarding the function of DNT cells. They contribute to inflammation and were found to act as regulatory $\mathrm{T}$ cells and/or cytotoxic $\mathrm{T}$ cells [54]. Their increase was noted in HIV infection, some lymphoproliferative disorders, graft-versus-host disease, and autoimmune diseases [43,55-57]. In this study, their relative count was increased in COVID-19 patients, despite the decreased absolute count. Additionally, a positive correlation was detected between DNT cells and the duration of fever. Thus, DNT cells might contribute to the pathogenesis of COVID through induction of proinflammatory responses or immune suppression with impaired immune responses to the SARS-CoV-2 virus.

Although in agreement with other studies [36,58,59], B cell absolute count was lower in COVID patients, while the relative count was elevated. A previous study found that patients with agammaglobulinemia had a mild course of COVID-19, suggesting a potential role of $\mathrm{B}$ lymphocytes in SARS-CoV-2-induced inflammation [60]. Inflammation is aggravating the COVID-19 clinical picture, as previously described, with a profound increase in the level of cytokines such as IL-6 [61]. Activated B cells produce IL- 6 to stimulate germinal center formation. This IL- 6 could increase the level of inflammation and contribute to the cytokine storm syndrome [60].

The NK cells play a vital role in the destruction of virus-infected cells and tumor cells $[62,63]$. NKT cells link the adaptive and innate immune system as they can produce large amounts of cytokines [64-66]. Agreeing with earlier studies [58,67], the NK and NKT cell counts decreased in our patients compared to the control group. 


\section{Conclusion}

Immune-inflammatory parameters are of utmost importance in understanding the pathogenesis and in the provisional diagnosis of COVID-19. Yet, adequate care must be taken during their interpretation due to the vast discrepancies observed among studies even in the same locality. Further studies are needed to clarify the role of B cells, DPT and DNT cells in the pathogenesis and control of COVID-19.

\section{References}

1. Fehr AR, Perlman S. Coronaviruses: an overview of their replication and pathogenesis. Coronaviruses: Springer; 2015. p. 1-23.

2. Chen N, Zhou M, Dong X, Qu J, Gong F, Han Y, et al. Epidemiological and clinical characteristics of 99 cases of 2019 novel coronavirus pneumonia in Wuhan, China: a descriptive study. Lancet 2020;395:507-13.

3. Lu R, Zhao X, Li J, Niu P, Yang B, Wu H, et al. Genomic characterisation and epidemiology of 2019 novel coronavirus: implications for virus origins and receptor binding. Lancet 2020;395:56574.

4. Channappanavar R, Perlman S. Pathogenic human coronavirus infections: causes and consequences of cytokine storm and immunopathology. Semin Immunopathol 2017;39:529-39.

5. Li T, Qiu Z, Zhang L, Han Y, He W, Liu Z, et al. Significant changes of peripheral $\mathrm{T}$ lymphocyte subsets in patients with severe acute respiratory syndrome. J Infect Dis 2004;189:648-51.

6. Wang D, Hu B, Hu C, Zhu F, Liu X, Zhang J, et al. Clinical characteristics of 138 hospitalized patients with 2019 novel coronavirus-infected pneumonia in Wuhan, China. JAMA 2020;323:1061-9.

7. Kermali M, Khalsa RK, Pillai K, Ismail Z, Harky A. The role of biomarkers in diagnosis of COVID-19-A systematic review. Life Sci 2020;254:117788.

8. Henry BM, De Oliveira MHS, Benoit S, Plebani M, Lippi G. Hematologic, biochemical and immune biomarker abnormalities associated with severe illness and mortality in coronavirus disease 2019 (COVID-19): a meta-analysis. Clin Chem Lab Med 2020;58:1021-8.

9. Salehi S, Abedi A, Balakrishnan S, Gholamrezanezhad A. Coronavirus disease 2019 (COVID-19): a systematic review of imaging findings in 919 patients. Am J Roentgenol 2020;215:8793.

10. Ye Z, Zhang Y, Wang Y, Huang Z, Song B. Chest CT manifestations of new coronavirus disease 2019 (COVID-19): a pictorial review. Eur Radiol 2020;30:4381-9.

11. Hansell DM, Bankier AA, MacMahon H, McLoud TC, Muller NL, Remy J. Fleischner Society: glossary of terms for thoracic imaging. Radiology 2008;246:697-722.

12. Pan F, Ye T, Sun P. Time course of lung changes on chest CT during recovery from 2019 novel coronavirus (COVID-19) pneumonia. Radiology 2020;295:715-21.

13. Debuc B, Smadja DM. Is COVID-19 a new hematologic disease? Stem Cell Rev Rep 2020;17:4-8.

14. Qin C, Zhou L, Hu Z, Zhang S, Yang S, Tao Y, et al. Dysregulation of immune response in patients with COVID-19 in Wuhan, China. Clin Infect Dis 2020;71:762-8.

15. Cao M, Zhang D, Wang Y, Lu Y, Zhu X, Li Y, et al. Clinical features of patients infected with the 2019 novel coronavirus (COVID-19) in Shanghai, China. MedRxiv 2020.03.04.20030395.

16. Velavan TP, Meyer CG. Mild versus severe COVID-19: laboratory markers. Int J Infect Dis 2020;95:304-7.

17. Sun Y, Koh V, Marimuthu K, Ng OT, Young B, Vasoo S, et al.
Epidemiological and clinical predictors of COVID-19. Clin Infect Dis 2020;71:786-92.

18. Guan WJ, Ni ZY, Hu Y, Liang WH, Ou CQ, He JX, et al. Clinical characteristics of coronavirus disease 2019 in China. N Engl J Med 2020;382:1708-20.

19. Khartabil T, Russcher H, van der Ven A, de Rijke Y. A summary of the diagnostic and prognostic value of hemocytometry markers in COVID-19 patients. Crit Rev Clin Lab Sci 2020;57:415-31.

20. Shoenfeld Y, Gurewich Y, Gallant L, Pinkhas J. Prednisoneinduced leukocytosis: influence of dosage, method and duration of administration on the degree of leukocytosis. Am J Med 1981;71:773-8.

21. Actor JK. Cells and organs of the immune system. Elsevier's Integrated Review. Immunology and Microbiology. Saunders; 2012. p. 7-16.

22. Agraz-Cibrian JM, Giraldo DM, Mary F-M, Urcuqui-Inchima S. Understanding the molecular mechanisms of NETs and their role in antiviral innate immunity. Virus Res 2017;228:124-33.

23. Brinkmann V, Reichard U, Goosmann C, Fauler B, Uhlemann Y, Weiss DS, et al. Neutrophil extracellular traps kill bacteria. Science 2004;303:1532-5.

24. Muraro SP, De Souza GF, Gallo SW, Da Silva BK, De Oliveira $\mathrm{SD}$, et al. Respiratory Syncytial Virus induces the classical ROSdependent NETosis through PAD-4 and necroptosis pathways activation. Sci Rep 2018;8:1-12.

25. Hiroki CH, Toller-Kawahisa JE, Fumagalli MJ, Colon DF, Figueiredo L, Fonseca BA, et al. Neutrophil extracellular traps effectively control acute chikungunya virus infection. Front Immunol 2020;10:3108.

26. Feng X, Li S, Sun Q, Zhu J, Chen B, Xiong M, et al. Immuneinflammatory parameters in COVID-19 cases: A systematic review and meta-analysis. Front Med 2020;7:301.

27. Yang AP, Liu J, Tao W, Li HM. The diagnostic and predictive role of NLR, d-NLR and PLR in COVID-19 patients. Int Immunopharmacol 2020:106504.

28. Yu H, Li D, Deng Z, Yang Z, Cai J, Jiang L, et al. Total protein as a biomarker for predicting coronavirus disease-2019 pneumonia. Available at SSRN: https://ssrn.com/abstract=3551289

29. Du Y, Tu L, Zhu P, Mu M, Wang R, Yang P, et al. Clinical features of 85 fatal cases of COVID-19 from Wuhan. A retrospective observational study. Am J Respir Crit Care Med 2020;201:1372-9.

30. Zhang J-J, Dong X, Cao Y-Y, Yuan Y-D, Yang Y-B, Yan Y-Q, et al. Clinical characteristics of 140 patients infected with SARS-CoV-2 in Wuhan, China. Allergy 2020;75:1730-41.

31. Flores-Torres AS, Salinas-Carmona MC, Salinas E, Rosas-Taraco AG. Eosinophils and respiratory viruses. Viral Immunol 2019;32:198-207.

32. Busse W, Chupp G, Nagase H, Albers FC, Doyle S, Shen Q, et al. Anti-IL-5 treatments in patients with severe asthma by blood eosinophil thresholds: Indirect treatment comparison. J Allergy Clin Immunol 2019;143:190-200.

33. Hassani M, Leijte G, Bruse N, Kox M, Pickkers P, Vrisekoop N, et al. Differentiation and activation of eosinophils in the human bone marrow during experimental human endotoxemia. J Leukocyte Biol 2020;108:1665-71.

34. Butterfield JH. Treatment of hypereosinophilic syndromes with prednisone, hydroxyurea, and interferon. Immunol Allergy Clin North Am 2007;27:493-518.

35. Chan M, Wong V, Wong C, Chan P, Chu C, Hui D, et al. Serum LD1 isoenzyme and blood lymphocyte subsets as prognostic indicators for severe acute respiratory syndrome. J Intern Med 2004;255:512-8.

36. Wang F, Nie J, Wang H, Zhao Q, Xiong Y, Deng L, et al. Characteristics of peripheral lymphocyte subset alteration in COVID-19 pneumonia. J Infect Dis 2020;221:1762-9.

37. Schmidt ME, Varga SM. The CD8 T cell response to respiratory 
virus infections. Front Immunol 2018;9:678.

38. Baazim H, Schweiger M, Moschinger M, Xu H, Scherer T, Popa A, et al. CD8+ T cells induce cachexia during chronic viral infection. Nat Immunol 2019;20:701-10.

39. Saeidi A, Zandi K, Cheok YY, Saeidi H, Wong WF, Lee CYQ, et al. T-cell exhaustion in chronic infections: reversing the state of exhaustion and reinvigorating optimal protective immune responses. Front Immunol 2018;9:2569.

40. Wang F, Hou H, Luo Y, Tang G, Wu S, Huang M, et al. The laboratory tests and host immunity of COVID-19 patients with different severity of illness. JCI Insight 2020;5:e137799.

41. Noulsri E, Lerdwana S, Fucharoen S, Pattanapanyasat K. Phenotypic characterization of circulating CD4/CD8 tlymphocytes in $\beta$-thalassemia patients. Asian Pac J Allergy Immunol 2014;32:261

42. Waschbisch A, Sammet L, Schröder S, Lee DH, Barrantes-Freer A, Stadelmann C, et al. Analysis of CD4+ CD8+ double-positive T cells in blood, cerebrospinal fluid and multiple sclerosis lesions. Clin Exp Immunol 2014;177:404-11.

43. Nascimbeni M, Shin E-C, Chiriboga L, Kleiner DE, Rehermann B. Peripheral CD4+ CD8+ T cells are differentiated effector memory cells with antiviral functions. Blood 2004;104:478-86.

44. Jiang M, Guo Y, Luo Q, Huang Z, Zhao R, Liu S, et al. T cell subset counts in peripheral blood can be used as discriminatory biomarkers for diagnosis and severity prediction of COVID-19. J Infect Dis 2020;222:198-202.

45. Wan S, Yi Q, Fan S, Lv J, Zhang X, Guo L, et al. Characteristics of lymphocyte subsets and cytokines in peripheral blood of 123 hospitalized patients with 2019 novel coronavirus pneumonia (NCP). MedRxiv 2020.02.10.20021832.

46. Liu J, Li S, Liu J, Liang B, Wang X, Wang H, et al. Longitudinal characteristics of lymphocyte responses and cytokine profiles in the peripheral blood of SARS-CoV-2 infected patients. EBioMedicine 2020;55:102763.

47. Overgaard NH, Jung JW, Steptoe RJ, Wells JW. CD4+/CD8+ double-positive $\mathrm{T}$ cells: more than just a developmental stage? J Leukocyte Biol 2015;97:31-8.

48. Reis BS, Rogoz A, Costa-Pinto FA, Taniuchi I, Mucida D. Mutual expression of the transcription factors Runx 3 and ThPOK regulates intestinal CD4+ T cell immunity. Nat Immunol 2013;14:271-80.

49. Sullivan YB, Landay AL, Zack JA, Kitchen SG, Al-Harthi L. Upregulation of CD4 on CD8+ T cells: CD4dimCD8bright T cells constitute an activated phenotype of CD8+ T cells. Immunology 2001;103:270-80.

50. Kitchen SG, Korin YD, Roth MD, Landay A, Zack JA. Costimulation of naive CD8+ lymphocytes induces CD4 expression and allows human immunodeficiency virus type 1 infection. J Virol 1998;72:9054-60.

51. Kitchen SG, Jones NR, LaForge S, Whitmire JK, Vu BA, Galic Z, et al. CD4 on CD8 $+\mathrm{T}$ cells directly enhances effector function and is a target for HIV infection. Proc Natl Acad Sci USA 2004;101:8727-32.

52. Kitchen SG, Whitmire JK, Jones NR, Galic Z, Kitchen CM,
Ahmed R, et al. The CD4 molecule on CD8+ T lymphocytes directly enhances the immune response to viral and cellular antigens. Proc Natl Acad Sci USA 2005;102:3794-9.

53. Bohner P, Chevalier MF, Cesson V, Rodrigues-Dias S-C, Dartiguenave F, Burruni R, et al. Double positive CD4+ CD8+ T cells are enriched in urological cancers and favor T Helper-2 polarization. Front Immunol 2019;10:622.

54. De Tullio G, Strippoli S, Angarano R, De Fazio V, Sgherza N, Negri A, et al. $\alpha \beta$-double negative CD4/CD8 (CD56) T cell (DNTs) in metastatic melanoma: basal frequency and behaviour during Ipilimumab treatment. Preliminary evaluations. J Transl Med 2015;13:1-3.

55. Quandt D, Rothe K, Scholz R, Baerwald CW, Wagner U. Peripheral CD4CD8 double positive T cells with a distinct helper cytokine profile are increased in rheumatoid arthritis. PloS One 2014;9:e93293.

56. Bristeau-Leprince A, Mateo V, Lim A, Magerus-Chatinet A, Solary E, Fischer A, et al. Human TCR alpha/beta+ CD4-CD8-doublenegative $T$ cells in patients with autoimmune lymphoproliferative syndrome express restricted Vbeta TCR diversity and are clonally related to CD8+ T cells. J Immunol 2008;181:440-8.

57. Mathiot ND, Krueger R, French MA, Price P. Percentage of CD3+ CD4-CD8- $\gamma \delta$ TCR-T Cells Is Increased by HIV Disease. AIDS Res Hum Retroviruses 2001; 17:977-80.

58. Tan M, Liu Y, Zhou R, Deng X, Li F, Liang K, et al. Immunopathological characteristics of coronavirus disease 2019 cases in Guangzhou, China. Immunology 2020;160:261-8.

59. Mazzoni A, Salvati L, Maggi L, Capone M, Vanni A, Spinicci M, et al. Impaired immune cell cytotoxicity in severe COVID-19 is IL-6 dependent. J Clin Invest 2020;130:4694-703.

60. Quinti I, Lougaris V, Milito C, Cinetto F, Pecoraro A, Mezzaroma I, et al. A possible role for B cells in COVID-19?: Lesson from patients with Agammaglobulinemia. J Allergy Clin Immunol 2020;146:211-3.

61. Cron RQ, WW Chatham. The rheumatologist's role in COVID-19. J Rheumatol 2020;47:639-42.

62. Bekaroğl M, Arslan B. Natural killer NK cells in $\beta$ thalassemia major patients. JSM Biotechnol Bioeng 2014;2:1040.

63. Ezer Ü, Gülderen F, Çulha VK, Akgül N, Gürbüz Ö. Immunological status of thalassemia syndrome. Pediatr Hematol Oncol 2002;19:51-8.

64. Godfrey DI, MacDonald HR, Kronenberg M, Smyth MJ, Van Kaer L. NKT cells: what's in a name? Nat Rev Immunol 2004;4:231-7.

65. Godfrey DI, Kronenberg M. Going both ways: immune regulation via CD1d-dependent NKT cells. J Clin Invest 2004;114:1379-88.

66. Wallace KL, Marshall MA, Ramos SI, Lannigan JA, Field JJ, Strieter RM, et al. NKT cells mediate pulmonary inflammation and dysfunction in murine sickle cell disease through production of IFN- $\gamma$ and CXCR3 chemokines. Blood 2009;114:667-76.

67. Odak I, Barros-Martins J, Bošnjak B, Stahl K, David S, Wiesner O, et al. Reappearance of effector $\mathrm{T}$ cells is associated with recovery from COVID-19. EBioMedicine 2020;57:102885. 